\title{
Prevention and treatment of the common cold: making sense of the evidence
}

\author{
G. Michael Allan MD, Bruce Arroll MB ChB PhD
}

Competing interests: Bruce Arroll organizes general lectures for the New Zealand government's Pharmaceutical

Management Agency.

No competing interests declared by Michael Allan.

This article has been peer reviewed.

Correspondence to: G. Michael Allan, michael.allan@ualberta.ca

CMAJ 2014. DOI:10.1503 /cmaj.121442
$\mathrm{T}$ he common cold is an acute, self-limiting viral infection of the upper respiratory tract involving the nose, sinuses, pharynx and larynx. The virus is spread by hand contact with secretions from an infected person (direct or indirect) or aerosol of the secretions and virus. ${ }^{1}$ The incubation period varies but is just under two days for rhinovirus. ${ }^{2}$ Symptoms, which generally relate to the infected mucosa, typically peak at 1-3 days and last 7-10 days, although they occasionally persist for three weeks. ${ }^{1,3-5}$ They include sore throat, rhinitis, rhinorrhea, cough and malaise. ${ }^{1.4}$ The severity and type of symptoms will vary among individuals and with different infective agents. For example, fever is common in children but rare and mild in adults. ${ }^{1}$ The incidence of the common cold declines with age. ${ }^{5-7}$ Children under two years have about six infections a year, adults two to three and older people about one per year. ${ }^{5-9}$ Stress $^{10}$ and poor sleep $^{11}$ may increase the risk of the common cold among adults, whereas attendance at a daycare cen$\mathrm{tre}^{12}$ increases the risk among preschool children.

Rhinovirus accounts for $24 \%-52 \%$ of clinical cases or $52 \%-76 \%$ of infections with an identified pathogen ${ }^{6-8,13}$ No pathogen is identified in $31 \%-57 \%$ of upper respiratory tract infections, ${ }^{8,13}$ likely because of a host of reasons, including poor collection technique, low pathogen count due to sampling late in the illness, or previously unidentified agents. ${ }^{1}$ Only about $5 \%$ of clinically diagnosed cases were found to have bacterial infection (with or without viral co-infection). ${ }^{13}$

Although self-limiting, the common cold is highly prevalent and may be debilitating. It causes declines in function and productivity at work ${ }^{14,15}$ and may affect other activities such as driving. ${ }^{16}$ Its impact on society and health care is large. Of individuals with an upper respiratory tract infection, $7 \%-17 \%$ of adults s.1. $^{178}$ and $33 \%$ of children ${ }^{17}$ visit a physician. Upper respiratory tract infections result in an estimated increase of $12.5 \%$ in patient visits per month during cold and flu season. ${ }^{19}$ In the United States, direct medical costs related to the common cold (physician visits, secondary infections and medications) were an estimated $\$ 17$ billion a year in $1997 .{ }^{17}$ Indirect costs owing to missed work because of illness or caring for an ill child were an estimated $\$ 25$ billion a year. ${ }^{17}$

We review the evidence underpinning preventive and treatment interventions for the common cold. We do not explore the proposed biologic mechanisms for the different products, because most are not substantiated and generally represent more supposition than science. The quality of the evidence was frequently poor, with a moderate to high risk of bias. Although preventive interventions have somewhat discrete outcomes (presence of an upper respiratory tract infection), interpretation of the evidence for treatment of the common cold is challenged by the complexity of outcome reporting. The evidence used in this review is described in Box 1.

\section{How can the common cold be distinguished from other conditions?}

The symptoms and signs of the common cold overlap with those of other conditions. Allergic rhinitis presents similarly, but it may have a seasonal component or clear allergic aggravation and is unlikely to have an accompanying sore throat. When sore throat is the primary complaint, streptococcal pharyngitis should be considered. Centor criteria ${ }^{20}$ are helpful in delineating the need for throat swabs and antibiotics.

Sinusitis (acute or subacute) is a clinical diagnosis without reliable clinical scoring criteria to help differentiate it from the common cold. Groups 
reviewing the evidence for the antibiotic treatment of sinusitis recommend that symptoms be present for 7-10 days and not show signs of improvement before antibiotics are considered. ${ }^{21,22}$

Ear pain and otitis media commonly accompany or follow the common cold, particularly in children. Findings on physical examination can be helpful in diagnosing otitis media (e.g., a bulging tympanic membrane has a likelihood ratio of 51), ${ }^{23}$ and there are simple rules for prescribing antibiotics or using watchful waiting in children with possible otitis media. ${ }^{24}$

People with influenza usually are sicker than those with the common cold, the former having fever, chills, headaches, myalgia and malaise. Influenza can be serious in older people and those who are immunocompromised. More serious illness should prompt consideration of meningococcal disease or septicemia.

More details regarding primary conditions whose signs and symptoms overlap with those of the common cold are available in guidelines and review articles on allergic rhinitis, ${ }^{25}$ sore throat, ${ }^{26}$ sinusitis, ${ }^{21}$ otitis media ${ }^{24}$ and influenza. ${ }^{27,28}$ In addition, the National Institute for Health and Care Excellence (NICE) has released a primary care guide for prescribing antibiotics for upper respiratory tract infections. ${ }^{29}$

\section{What interventions are effective for preventing the common cold?}

Preventive therapies are summarized in Table $1 .^{30-50}$

\section{Physical interventions}

A Cochrane systematic review examined the effectiveness of traditional physical public health interventions in preventing upper respiratory tract infections in 67 studies of various types (randomized controlled trials [RCTs], cluster RCTs, retrospective and prospective cohort studies, casecontrol studies and before-after studies) ${ }^{30}$ The type of interventions varied considerably - handwashing, use of alcohol-based disinfectants, other disinfectants, hand-wipes, gloves, masks, gowns and various combinations. As a result, pooling of data was limited, and many of the studies had an unclear or high risk of bias. Nevertheless, the majority of results suggested that physical preventive measures such as handwashing reduced the risk of getting or spreading upper respiratory tract infections.

\section{Zinc}

Zinc appears to be effective in reducing the number of colds per year, at least in children. A Cochrane review $^{31}$ of the prophylactic efficacy of orally administered zinc considered two RCTs that we also examined individually. ${ }^{32,33}$ These studies had methodologic concerns and included only children given zinc sulfate $10 \mathrm{mg}$ or $15 \mathrm{mg}$ daily. The mean number of colds was significantly lower in the zinc group than in the placebo group both in the pooled analysis (Table 1) and in the individual studies (mean $1.2 \mathrm{v} .1 .7[p=0.003]$ in one trial ${ }^{32}$ and $1.7 \mathrm{v}$. $3.1[p<0.001]$ in the other $\left.{ }^{33}\right)$. School absences were significantly lower in the zinc groups of each study, by an average of 0.4 days $(p=0.04)^{32}$ and 0.8 days $(p<0.001) .^{33}$ Antibiotic use was also significantly lower in the zinc groups of each study $(5 \mathrm{v}$. $18[p=0.009]^{32}$ and 20 v. $47[p<0.001]^{33}$ respectively). In one of the studies, ${ }^{32}$ the proportion of children with no colds during the study period was $33 \%$ in the zinc group versus $14 \%$ in the control group, for a number needed to treat of six.

Although the evidence for cold prevention with zinc comes from studies involving only children, there is no biological reason why zinc would work only in children and not adults.

\section{Probiotics}

Probiotics may be helpful in preventing upper respiratory tract infections, but the interventions and evidence are inconsistent. A systematic review of 14 RCTs included 10 trials $(n=3451)$ that provided sufficient data for pooling. ${ }^{34}$ Pediatric and adult populations from a wide variety of countries were included. Probiotic prophylaxis reduced the number of participants who had one or more upper respiratory tract infections (odds ratio [OR] $0.58,95 \%$ confidence interval $[\mathrm{CI}] 0.36$ to 0.92 ) and the number of upper respiratory tract infections per person-year (rate ratio $0.88,95 \%$ CI 0.81 to 0.96 ). Both outcomes had inconsistent results in the individual studies, reflected in estimates of heterogeneity $\left(I^{2}=69 \%\right.$ and $44 \%$, respectively).

\section{Box 1: Summary of literature review}

In July and August 2012, a literature search was performed by one of us (G.M.A.) of PubMed, the Cochrane Database of Systematic Reviews, ACP Journal Club and Evidence-Based Medicine. Search terms included "common cold" and "upper respiratory tract infection." In PubMed, the search was restricted to randomized controlled trials (RCTs), reviews, systematic reviews and meta-analyses. Individual treatments were also searched (e.g., "vitamin C"). A similar search was performed in early 2012 by B.A. for a related project. We conducted a manual search of the bibliographies of included articles. Further details of the literature search are available from the authors upon request.

We selected the highest level of evidence available for each intervention, focusing on systematic reviews (with or without a meta-analysis) and RCTs. We rated the quality of evidence for each intervention as high, moderate or low risk of bias. For systematic reviews, we considered the authors' assessment of methodologic quality (e.g., blinding) of included trials but also examined the quality of the systematic review itself (e.g., thoroughness of the literature search). For RCTs, we considered traditional validity criteria (e.g., allocation concealment) as well other limitations (e.g., funding or restricted populations). Lastly, we considered the overall volume (size and number of RCTs) and the consistency of the evidence. We used lower levels of evidence for general information such as epidemiology. 
However, use of probiotics reduced antibiotic use (risk ratio $0.67,95 \%$ CI 0.45 to 0.98 ). In all but two studies, the probiotics varied in types of organisms, combinations of organisms, formulations (e.g., pills, liquids) and quantity (colonyforming units). These inconsistencies limit the clinical application of the study findings.

We examined the two highest-quality studies included in the systematic review. In the first, ${ }^{35} 638$ children aged three to six years attending a community preschool or daycare were randomly assigned to receive either a drink containing the probiotic strain Lactobacillus casei DN-114 001 (10 colonyforming units) or a matching placebo for 90 days. Use of the probiotic resulted in a reduction of 0.6 upper respiratory tract infections per 100 persondays $(p=0.036)$. In the second RCT, ${ }^{36} 742$ children more than 12 months of age who were admitted to hospital were randomly assigned to drink $100 \mathrm{~mL}$ of a fermented milk product containing either Lac- tobacillus rhamnosus strain GG $\left(10^{9}\right.$ colonyforming units) or no probiotic for the duration of their hospital stay. The incidence of upper respiratory tract infections was reduced in the probiotic group (relative risk $0.38,95 \%$ CI 0.18 to 0.85 ), for a number needed to treat of 30 .

\section{Gargling}

Frequent gargling with water may help reduce episodes of upper respiratory tract infection, but evidence is limited to a single study. The welldesigned RCT involved 387 adults randomly assigned to gargling with water, gargling with a diluted povidone-iodine solution or usual care (control). ${ }^{37}$ Gargling with the povidone-iodine solution had no effect, whereas gargling with water was effective in reducing the risk of an upper respiratory tract infection $(30.1 \%$ v. $40.8 \%$ in the control group; $p=0.044$ ), for a number needed to treat of 10 . The degree of gargling

Table 1 (part 1 of 2): Interventions for the prevention of the common cold

\begin{tabular}{|c|c|c|c|c|c|c|}
\hline Intervention & $\begin{array}{l}\text { Formulation } \\
\text { and dose }\end{array}$ & Evidence & Risk of bias & Outcome & Harms & Comment \\
\hline $\begin{array}{l}\text { Physical } \\
\text { intervention }\end{array}$ & $\begin{array}{l}\text { Various techniques } \\
\text { (e.g., handwashing, use } \\
\text { of alcohol-based hand } \\
\text { disinfectant, gloves, } \\
\text { masks) }\end{array}$ & $\begin{array}{l}\text { Systematic review } \\
\text { of } 67 \text { studies } \\
\text { (various types) }\end{array}$ & $\begin{array}{l}\text { High (studies had } \\
\text { unclear risk of bias } \\
\text { for most quality } \\
\text { indicators) }\end{array}$ & $\begin{array}{l}\text { General reduced risk } \\
\text { with handwashing, } \\
\text { hand disinfectant, } \\
\text { gloves and masks }\end{array}$ & $\begin{array}{l}\text { N95 masks offered } \\
\text { no advantage over } \\
\text { normal surgical } \\
\text { masks, were } \\
\text { uncomfortable and } \\
\text { irritated the skin }\end{array}$ & $\begin{array}{l}\text { Likely } \\
\text { beneficial }\end{array}$ \\
\hline $\begin{array}{l}\text { Zinc } \\
\text { supplement }{ }^{31-33}\end{array}$ & $\begin{array}{l}\text { Zinc sulfate tablets, } \\
10 \mathrm{mg} \text { and } 15 \mathrm{mg}\end{array}$ & $\begin{array}{l}\text { Meta-analysis } \\
\text { ( } 2 \text { RCTs; } n=400 \text {, } \\
\text { age } 5-8 \text { yr) }\end{array}$ & $\begin{array}{l}\text { High (unclear } \\
\text { randomization; } \\
\text { and events } \\
\text { censored from } \\
\text { analysis for } \\
\text { unclear reasons }{ }^{32} \text { ) }\end{array}$ & $\begin{array}{l}\text { Pooled analysis of } \\
2 \text { RCTs: significant } \\
\text { reduction in colds } \\
\text { (RR } 0.64,95 \% \mathrm{Cl} 0.47 \text { to } \\
0.88 \text { ); about } 0.5-1.4 \\
\text { fewer colds over } 5-7 \\
\text { "winter" months }\end{array}$ & $\begin{array}{l}3 \text { children in the } \\
\text { intervention group } \\
\text { in one RCT had mild } \\
\text { gastrointestinal } \\
\text { discomfort; no other } \\
\text { significant } \\
\text { differences noted }\end{array}$ & $\begin{array}{l}\text { Likely } \\
\text { beneficial }\end{array}$ \\
\hline Probiotics $^{34-36}$ & $\begin{array}{l}\text { Different organisms, } \\
\text { combinations, } \\
\text { formulations and quantity; } \\
\text { Lactobacillus most } \\
\text { common (rhamnosus, } \\
\text { casei and other species) }\end{array}$ & $\begin{array}{l}\text { Systematic review } \\
\text { and meta-analysis } \\
(10 \text { RCTs; } n=3451) \text {, } \\
\text { with focus on } 2 \\
\text { RCTs of highest } \\
\text { quality }\end{array}$ & $\begin{array}{l}\text { Moderate ( } \leq 50 \% \\
\text { of the trials were } \\
\text { low risk of bias for } \\
\text { quality indicators) }\end{array}$ & $\begin{array}{l}\text { Pooled analysis of } 6 \text { RCTs: } \\
\text { significant reduction in } \\
\text { number with } \geq 1 \text { colds } \\
\text { (OR } 0.58,95 \% \text { Cl } 0.36 \text { to } \\
0.92) ; \text { results of RCTs were } \\
\text { inconsistent }\left(I^{2}=69 \%\right)\end{array}$ & $\begin{array}{l}\text { No difference } \\
\text { noted }\end{array}$ & $\begin{array}{l}\text { May be } \\
\text { beneficial }\end{array}$ \\
\hline Gargling $^{37}$ & $\begin{array}{l}\text { Tap water or diluted } \\
\text { povidone-iodine }(7 \%) \\
\text { solution, } 20 \mathrm{~mL} \text { gargled } \\
\text { for } 15 \text { s } 3 \text { times per } \\
\text { session; repeated at } \\
\text { least } 3 \text { times daily }\end{array}$ & $\mathrm{RCT}(n=384)$ & $\begin{array}{l}\text { Low (allocation } \\
\text { concealment and } \\
\text { blinded outcome } \\
\text { assessment) }\end{array}$ & $\begin{array}{l}\text { Significantly fewer URTIs } \\
\text { with gargling water } \\
\text { (RR 0.64, } 95 \% \text { Cl } 0.42 \text { to } \\
0.99 \text { ); no significant } \\
\text { reduction with gargling } \\
\text { povidone-iodine (RR } 0.87 \text {, } \\
95 \% \text { Cl } 0.58 \text { to } 1.34 \text { ) }\end{array}$ & Not reported & $\begin{array}{l}\text { Unclear benefit } \\
\text { from water } \\
\text { gargling; no } \\
\text { benefit from } \\
\text { gargling of } \\
\text { iodine solution }\end{array}$ \\
\hline Ginseng $^{38-40}$ & $\begin{array}{l}\text { North American } \\
\text { ginseng as COLD-FX } \\
\text { brand in } 5 \text { of } 6 \text { RCTs } \\
\text { ( } 400 \text { mg generally); } \\
\text { Asian ginseng as } \\
\text { Ginsana G115 brand }\end{array}$ & $\begin{array}{l}\text { Systematic } \\
\text { review (5 RCTs; } \\
n=747) \\
\text { and single RCT } \\
(n=783)\end{array}$ & $\begin{array}{l}\text { High (multiple } \\
\text { variations of } \\
\text { analysis) }\end{array}$ & $\begin{array}{l}\text { Pooled analysis of } 5 \text { RCTs: } \\
\text { no significant reduction in } \\
\text { colds (relative risk } 0.70 \text {, } \\
95 \% \mathrm{Cl} 0.48 \text { to } 1.02) \text {; results } \\
\text { of RCTs were inconsistent } \\
\left(P^{2}=68 \%\right) \\
\text { Analysis of single RCT: no } \\
\text { significant difference } \\
\text { from placebo }(p=0.23)\end{array}$ & $\begin{array}{l}\text { No consistent } \\
\text { difference }\end{array}$ & $\begin{array}{l}\text { Unclear } \\
\text { benefit }\end{array}$ \\
\hline Exercise $^{41}$ & $\begin{array}{l}45 \text { min of moderate- } \\
\text { intensity exercise } \\
5 \mathrm{~d} / \mathrm{wk}\end{array}$ & $\begin{array}{l}\text { RCT }(n=115 \\
\text { overweight } \\
\text { or obese } \\
\text { postmenopausal } \\
\text { women) }\end{array}$ & $\begin{array}{l}\text { High (unclear } \\
\text { allocation } \\
\text { concealment and } \\
\text { equivocal findings) }\end{array}$ & $\begin{array}{l}\text { Significantly fewer self- } \\
\text { reported colds per person- } \\
\text { year in intervention group } \\
\text { (0.55 v. } 0.96 \text { in control } \\
\text { group, } p=0.02) \text {; no } \\
\text { difference in URTls } \\
\text { between groups }(p=0.16)\end{array}$ & Not reported & $\begin{array}{l}\text { Unclear } \\
\text { benefit }\end{array}$ \\
\hline
\end{tabular}


required was considerable $(20 \mathrm{~mL}$ for $15 \mathrm{sec}$ onds repeated three times, performed three times daily). Confirmation from a second RCT would be helpful before recommending gargling.

\section{Ginseng}

The role of ginseng in preventing colds is questionable. A familiar product in Canada is COLDFX, a proprietary extract produced from the roots of North American ginseng (Panax quinquefolius). A meta-analysis ${ }^{38}$ of five RCTs (four of COLD-FX and one of Asian ginseng [P. ginseng]) and one $\mathrm{RCT}^{39}$ of COLD-FX have provided inconsistent results. Some of the trials showed a statistically significant reduction in laboratory-confirmed colds and influenza, whereas others found small changes in clinical, but not laboratory-confirmed, upper respiratory tract infections only. ${ }^{40}$ Trials of COLD-FX were found to have multiple problems, including dropout rates above $10 \%$ before a single dose was taken, post-hoc modification of analyses to achieve statistical significance (per-protocol analysis, combination of trials or selection of certain time frames), multiple analyses, a focus on laboratory (not clinical) outcomes and inconsistent results. ${ }^{40}$

\section{Other interventions}

A variety of other interventions have been studied for the prevention of the common cold. Studies of exercise, ${ }^{41}$ garlic ${ }^{42,43}$ and homeopathy ${ }^{4-46}$ showed unclear evidence of benefit, whereas those of vitamin $\mathrm{D}^{48,49}$ and echinacea ${ }^{50}$ showed no evidence of benefit. Vitamin $\mathrm{C}^{47}$ may provide some benefit in people under physical stress (e.g., marathon runners or soldiers in subarctic environments), but no meaningful benefit has been shown for the average patient.

Table 1 (part 2 of 2): Interventions for the prevention of the common cold

\begin{tabular}{|c|c|c|c|c|c|c|}
\hline Intervention & $\begin{array}{l}\text { Formulation } \\
\text { and dose }\end{array}$ & Evidence & Risk of bias & Outcome & Harms & Comment \\
\hline $\begin{array}{l}\text { Garlic } \\
\text { supplement }{ }^{42,43}\end{array}$ & $\begin{array}{l}\text { Allicin powder } \\
180 \mathrm{mg}\end{array}$ & $\begin{array}{l}\text { Meta-analysis } \\
(1 \mathrm{RCT} ; n=146)\end{array}$ & $\begin{array}{l}\text { High ( } 1 \text { trial had } \\
\text { unclear allocation } \\
\text { concealment) }\end{array}$ & $\begin{array}{l}73 \text { participants in } \\
\text { each group; over } 90-d \\
\text { period, } 24 \text { colds in } \\
\text { intervention group v. } \\
65 \text { in control group } \\
(p<0.001) \text {; unclear } \\
\text { how many had no } \\
\text { colds }\end{array}$ & $\begin{array}{l}\text { Not reported } \\
\text { (other than } 4 \\
\text { taking garlic and } \\
1 \text { taking placebo } \\
\text { having a smell } \\
\text { when burping) }\end{array}$ & Unclear benefit \\
\hline Homeopathy ${ }^{44-46}$ & $\begin{array}{l}\text { Multiple different } \\
\text { treatments }\end{array}$ & $\begin{array}{l}3 \text { RCTs ( } n=170, \\
142 \text { and } 199 \\
\text { children, } \\
\text { respectively, aged } \\
\leq 10 \text { yr) }\end{array}$ & $\begin{array}{l}\text { Moderate ( } 2 \text { trials } \\
\text { had } 15 \%-23 \% \\
\text { drop out before } \\
\text { first dose; } 1 \text { was } \\
\text { nonblinded) }\end{array}$ & $\begin{array}{l}2 \text { placebo-controlled } \\
\text { RCTs: no significant } \\
\text { effect; } 1 \text { RCT with } \\
\text { wait-list control } \\
\text { showed reduced } \\
\text { symptoms and days ill }\end{array}$ & $\begin{array}{l}1 \text { of } 3 \text { RCTs } \\
\text { reported adverse } \\
\text { events; } 22 \% \text { had } \\
\text { mild and } \\
\text { transient adverse } \\
\text { effects, but } \\
\text { control group } \\
\text { not mentioned }\end{array}$ & $\begin{array}{l}\text { Unclear (likely } \\
\text { no) benefit }\end{array}$ \\
\hline Vitamin $\mathrm{C}^{47}$ & $\begin{array}{l}\text { Vitamin C } 0.2-3 \mathrm{~g} / \mathrm{d} \\
(1 \mathrm{~g} / \mathrm{d} \text { most common })\end{array}$ & $\begin{array}{l}\text { Meta-analysis } \\
(29 \text { RCTs; } n= \\
11 \text { 306) }\end{array}$ & $\begin{array}{l}\text { Unclear (reviewers } \\
\text { used blinding as } \\
\text { surrogate of } \\
\text { allocation } \\
\text { concealment) }\end{array}$ & $\begin{array}{l}\text { Community } \\
\text { participants: no effect } \\
\text { (RR } 0.97,95 \% \mathrm{Cl} 0.94 \\
\text { to } 1.00 \text { ); participants } \\
\text { exposed to cold or } \\
\text { heavy physical stress: } \\
\text { fewer colds (RR } 0.48 \text {, } \\
95 \% \mathrm{Cl} 0.35 \text { to } 0.64 \text { ). } \\
\text { Duration shorter than } \\
\text { with placebo (mean } \\
\text { difference }-9.1 \% \text {, } \\
95 \% \mathrm{Cl}-12.6 \% \text { to } \\
-5.6 \% \text { ). Effect not } \\
\text { better with higher } \\
\text { dose }\end{array}$ & None reported & $\begin{array}{l}\text { No benefit } \\
\text { (no meaningful } \\
\text { benefit in the } \\
\text { average patient) }\end{array}$ \\
\hline Vitamin $D^{48,49}$ & $\begin{array}{l}\text { Vitamin D } 400 \mathrm{IU} \\
\text { daily; } 200000 \mathrm{IU} \\
\text { monthly for } 2 \mathrm{mo} \text {, } \\
\text { then } 100000 \\
\text { monthly }\end{array}$ & $\begin{array}{l}2 \text { RCTs ( } n=164 \\
\text { male military } \\
\text { recruits, } 322 \\
\text { health workers or } \\
\text { students) }\end{array}$ & $\begin{array}{l}\text { Moderate (high } \\
\text { risk of bias in one } \\
\text { trial, low risk in } \\
\text { the other trial) }\end{array}$ & No consistent benefit & Likely none & No benefit \\
\hline Echinacea $^{50}$ & $\begin{array}{l}\text { Echinacea purpurea, } \\
\text { E. angustifolia } \\
\text { (pressed juice or } \\
\text { extract in different } \\
\text { dilutions and } \\
\text { volumes) }\end{array}$ & $\begin{array}{l}\text { Systematic review } \\
(2 \mathrm{RCTs} ; n=519)\end{array}$ & Low & $\begin{array}{l}3 \text { comparisons, not } \\
\text { pooled: none showed } \\
\text { statistical difference } \\
\text { from placebo in } \\
\text { preventing colds }\end{array}$ & $\begin{array}{l}\text { No significant } \\
\text { difference from } \\
\text { placebo }\end{array}$ & No benefit \\
\hline
\end{tabular}


Summarized details of these interventions can be found in Table 1. See also Appendix 1 (available at www.cmaj.ca/lookup/suppl/doi:10.1503 /cmaj.121442/-/DC1) for a more detailed discussion of each intervention.

\section{What medications are effective for treating the common cold?}

The traditional pharmacologic treatments of the common cold are summarized in Table 2. ${ }^{51-66}$

\section{Antihistamines, monotherapy}

Antihistamines as monotherapy have no meaningful effect in the treatment of the common cold. ${ }^{51,52}$ A recent meta-analysis showed no significant improvement in general symptoms for this intervention (Peto OR 0.97, 95\% CI 0.85 to 1.12); multiple sensitivity and subgroup analyses did not alter the finding in a meaningful way. ${ }^{52}$ Although statistical significance was reached for some nasal symptoms, clinical significance $(\leq 0.3$ change on 4-5-point scale) was reached for none. An earlier meta-analysis had similar results. ${ }^{51}$

\section{Antihistamines, combination therapy}

Antihistamines combined with decongestants, analgesics or both appear to have a small to moderate effect on the common cold in older children and adults. A large systematic review and meta-analysis ${ }^{53}$ found that the antihistaminedecongestant combination reduced global symptoms in six pooled studies (OR $0.27,95 \%$ CI 0.15 to 0.50 ). The estimated number needed to treat was five. Although overall adverse events were not increased, there were significant increases in dry mouth (OR 3.77, 95\% CI 1.75 to 8.14 ) and insomnia (OR $3.02,95 \%$ CI 1.08 to 8.47). Fewer, and smaller, RCTs examined other combinations, and pooling was limited. For the antihistamine-analgesic combination, two of three studies reported on global symptoms and found significant improvement. For the antihistamine-decongestant-analgesic combination compared with placebo, four trials reported improve-

Table 2 (part 1 of 2): Pharmacologic interventions for the treatment of the common cold

\begin{tabular}{|c|c|c|c|c|c|c|}
\hline Intervention & $\begin{array}{l}\text { Formulation } \\
\text { and dose }\end{array}$ & Evidence & Risk of bias & Outcome & Harms & Comment \\
\hline $\begin{array}{l}\text { Antihistamine, } \\
\text { monotherapy }{ }^{51,52}\end{array}$ & $\begin{array}{l}\text { Various } \\
\text { antihistamines }\end{array}$ & $\begin{array}{l}2 \text { meta-analyses } \\
\text { (9 RCTs in first, } n= \\
1023 \text { adults; } 32 \text { RCTs } \\
\text { in second, } n=8930 \\
\text { adults and children); } \\
\text { total } 22 \text { RCTs }\end{array}$ & $\begin{array}{l}\text { Moderate (some } \\
\text { trial quality issues } \\
\text { and conflicting } \\
\text { results) }\end{array}$ & $\begin{array}{l}\text { Overall symptoms and } \\
\text { nasal obstruction not } \\
\text { improved; subjective } \\
\text { improvement in } \\
\text { rhinorrhea and } \\
\text { sneezing at days } 2-4 \\
\text { statistically significant } \\
\text { but not clinically } \\
\text { significant (scores } \\
\text { generally } \leq 0.3 \text { on } \\
\text { scale of } 4-5 \text { ) }\end{array}$ & $\begin{array}{l}\text { Adverse events } \\
\text { (primarily sedation) } \\
\text { increased with } \\
\text { first-generation } \\
\text { antihistamines } \\
\text { (Peto OR 1.25, } \\
95 \% \mathrm{Cl} 1.04-1.50 \text { ); } \\
\text { no increase with } \\
\text { nonsedating } \\
\text { antihistamines }\end{array}$ & $\begin{array}{l}\text { No clinically } \\
\text { meaningful } \\
\text { benefit }\end{array}$ \\
\hline $\begin{array}{l}\text { Antihistamine, } \\
\text { combination } \\
\text { therapy }^{53}\end{array}$ & $\begin{array}{l}\text { Antihistamine plus } \\
\text { decongestant or } \\
\text { analgesic or both }\end{array}$ & $\begin{array}{l}\text { Meta-analysis } \\
\text { ( } 27 \text { RCTs; } n=5117 \\
\text { adults and children) }\end{array}$ & $\begin{array}{l}\text { High (trial quality } \\
\text { issues common, } \\
\text { and conflicting } \\
\text { results) }\end{array}$ & $\begin{array}{l}\text { Best evidence for } \\
\text { antihistamine- } \\
\text { decongestant } \\
\text { combination (NNT = } 5 \\
\text { for global symptoms); } \\
\text { other combinations } \\
\text { had small to } \\
\text { moderate effects in } \\
\text { adults and older } \\
\text { children }\end{array}$ & $\begin{array}{l}\text { Some increased } \\
\text { adverse events } \\
\text { (insomnia and } \\
\text { dry mouth) with } \\
\text { antihistamine- } \\
\text { decongestant } \\
\text { combination; } \\
\text { no statistically } \\
\text { significant } \\
\text { differences with } \\
\text { other combinations }\end{array}$ & $\begin{array}{l}\text { Likely } \\
\text { beneficial in } \\
\text { adults and } \\
\text { older children; } \\
\text { no effect in } \\
\text { children } \leq 5 \text { yr }\end{array}$ \\
\hline Decongestant $^{54-57}$ & $\begin{array}{l}\text { Oral } \\
\text { phenylephrine and } \\
\text { topical nasal } \\
\text { decongestant }\end{array}$ & $\begin{array}{l}3 \text { meta-analyses and } \\
1 \text { systematic review } \\
\text { (4-15 RCTs) }\end{array}$ & $\begin{array}{l}\text { High (limited } \\
\text { quality } \\
\text { information } \\
\text { available) }\end{array}$ & $\begin{array}{l}\text { Oral and topical } \\
\text { decongestants: small, } \\
\text { statistically significant } \\
\text { effect on nasal airway } \\
\text { resistance, but no } \\
\text { consistent clinical } \\
\text { effect; no data for } \\
\text { children }\end{array}$ & $\begin{array}{l}\text { No consistent } \\
\text { effect on heart rate } \\
\text { or blood pressure; } \\
\text { small increase in } \\
\text { insomnia }\end{array}$ & $\begin{array}{l}\text { Small benefit } \\
\text { but uncertain } \\
\text { clinical } \\
\text { significance; } \\
\text { no data for } \\
\text { children }\end{array}$ \\
\hline $\begin{array}{l}\text { Intranasal } \\
\text { ipratropium }^{58}\end{array}$ & $\begin{array}{l}\text { Ipratropium } \\
42-168 \mu \mathrm{g} \\
\text { (1-2 sprays } 3-4 \\
\text { times per day) }\end{array}$ & $\begin{array}{l}\text { Meta-analysis } \\
\text { (7 RCTs; } n=2144 \\
\text { adults and children } \\
\geq 5 \mathrm{yr} \text { ) }\end{array}$ & $\begin{array}{l}\text { Moderate (some } \\
\text { trial quality } \\
\text { issues) }\end{array}$ & $\begin{array}{l}\text { Improved rhinorrhea } \\
\text { but not nasal } \\
\text { congestion; at } 24 \mathrm{~h} \text {, } \\
87 \% \text { of ipratropium } \\
\text { group v. } 73 \% \text { of } \\
\text { control group rated } \\
\text { themselves as much } \\
\text { better or better ( } p= \\
0.004 \text { ) }\end{array}$ & $\begin{array}{l}\text { Increased epistaxis, } \\
\text { nasal dryness and } \\
\text { mouth dryness }\end{array}$ & $\begin{array}{l}\text { Probable } \\
\text { benefit }\end{array}$ \\
\hline
\end{tabular}


ment in global symptoms and two found statistically significant improvement.

We found no evidence of effectiveness of antihistamines combined with decongestants, analgesics or both in younger children (age $\leq 5$ ), and Health Canada recommends against use in this age group. ${ }^{67}$ Adverse events were significantly increased with antihistamine-analgesic and antihistamine-decongestant-analgesic combinations, but pooled estimates were small and may not reflect actual clinical results.

\section{Decongestants}

Decongestants result in small improvements of uncertain clinical significance in nasal symptoms, according to three meta-analyses ${ }^{54-56}$ and a systematic review. ${ }^{57}$ Oral decongestants were shown to decrease subjective nasal symptoms by $6 \%$ with a single dose and $4 \%$ with recurrent doses, but clinical relevance is uncertain. ${ }^{56}$ Although phenylephrine (10-25 mg orally) was found to reduce nasal airway resistance by about $10 \%(p<$ $0.05)$, the clinical meaning of this outcome is uncertain. ${ }^{54,55}$ Fourteen of 26 studies did not report significant improvement in any subjective clinical outcome..$^{55}$ A single RCT of nasal xylometazoline monotherapy found positive effects, but the trial may have selectively reported positive outcomes and was funded by the manufacturer. ${ }^{57}$ Children were not represented in trials of topical decongestants, and Health Canada recommends against use in this age group. ${ }^{67}$

\section{Intranasal ipratropium}

Inhaled ipratropium bromide appears to improve cold symptoms, particularly rhinorrhea, with a moderate increase in adverse events such as epistaxis and dryness of the nose and mouth. A systematic review and meta-analysis of intranasal ipratropium bromide spray did not pool data because of variability in scales, measurements and other parameters. ${ }^{58}$ Four RCTs identified in the systematic review reported statistically significant improvement in rhinorrhea symptoms compared with placebo. However, four other RCTs found no improvement in nasal congestion compared with

Table 2 (part 2 of 2): Pharmacologic interventions for the treatment of the common cold

\begin{tabular}{|c|c|c|c|c|c|c|}
\hline Intervention & $\begin{array}{l}\text { Formulation } \\
\text { and dose }\end{array}$ & Evidence & Risk of bias & Outcome & Harms & Comment \\
\hline $\begin{array}{l}\text { Over-the-counter } \\
\text { cough } \\
\text { treatments }^{58}\end{array}$ & $\begin{array}{l}\text { Antitussives, } \\
\text { antihistamines, } \\
\text { mucolytics, } \\
\text { expectorants, alone } \\
\text { or in combination* }\end{array}$ & $\begin{array}{l}\text { Meta-analysis } \\
\text { (8 RCTs, } n=616 \\
\text { children; } 18 \text { RCTs, } \\
n=3421 \text { adults) }\end{array}$ & $\begin{array}{l}\text { High (multiple } \\
\text { trial quality } \\
\text { issues and } \\
\text { conflicting } \\
\text { results) }\end{array}$ & $\begin{array}{l}\text { Children: no benefit } \\
\text { Adults: some } \\
\text { inconsistent benefit } \\
\text { with some } \\
\text { combinations and } \\
\text { dextromethorphan }\end{array}$ & $\begin{array}{l}\text { Inconsistently } \\
\text { reported }\end{array}$ & $\begin{array}{l}\text { No benefit in } \\
\text { children; } \\
\text { benefit } \\
\text { unclear (but } \\
\text { likely small) in } \\
\text { adults }\end{array}$ \\
\hline Vapour rub ${ }^{59}$ & $\begin{array}{l}\text { 5-10 mL rubbed on } \\
\text { chest and neck one } \\
\text { night }\end{array}$ & $\begin{array}{l}\mathrm{RCT}(n=138 \\
\text { children, } \\
\text { age } 2-11 \mathrm{yr})\end{array}$ & $\begin{array}{l}\text { Moderate } \\
\text { (poorly described } \\
\text { randomization, } \\
\text { blinding limited, } \\
\text { single study) }\end{array}$ & $\begin{array}{l}\text { No improvement in } \\
\text { cough or rhinorrhea but } \\
\text { small improvement in } \\
\text { sleep for child and } \\
\text { parent compared with } \\
\text { placebo }\end{array}$ & $\begin{array}{l}\text { Significant } \\
\text { increase in } \\
\text { adverse events } \\
\text { (burning of skin, } \\
\text { eyes and nose) }\end{array}$ & $\begin{array}{l}\text { Unclear } \\
\text { benefit, but } \\
\text { harms present }\end{array}$ \\
\hline NSAID ${ }^{60}$ & $\begin{array}{l}7 \text { different NSAIDs } \\
\text { used (ibuprofen } \\
\text { most common) }\end{array}$ & $\begin{array}{l}\text { Meta-analysis } \\
\text { (9 RCTs; } n=1069 \\
\text { adults) }\end{array}$ & $\begin{array}{l}\text { Moderate (main } \\
\text { limitation was } \\
\text { missing } \\
\text { information on } \\
\text { randomization) }\end{array}$ & $\begin{array}{l}\text { No improvement in } \\
\text { duration of cold, overall } \\
\text { symptoms or most } \\
\text { respiratory symptoms; } \\
\text { improvement in some } \\
\text { pain areas (ear, muscles, } \\
\text { headache) but not sore } \\
\text { throat }\end{array}$ & $\begin{array}{l}\text { Nonsignificant } \\
\text { trend to } \\
\text { increased } \\
\text { adverse events } \\
\text { (risk ratio } 2.94 \text {, } \\
95 \% \mathrm{Cl} 0.51 \text { to } \\
17.03 \text { ) }\end{array}$ & $\begin{array}{l}\text { Likely } \\
\text { beneficial for } \\
\text { pain; no } \\
\text { benefit for } \\
\text { other } \\
\text { symptoms }\end{array}$ \\
\hline $\begin{array}{l}\text { Acetaminophen } \\
\text { (paracetamol) }^{61-64}\end{array}$ & $\begin{array}{l}1000 \mathrm{mg} 4 \text { times } \\
\text { daily in adults or } 15 \\
\mathrm{mg} / \mathrm{kg} \text { in children }\end{array}$ & $\begin{array}{l}2 \text { RCTs ( } n=90 \\
\text { children, } 392 \\
\text { adults), plus } 2 \text { meta- } \\
\text { analyses focused on } \\
\text { fever }\end{array}$ & $\begin{array}{l}\text { Moderate (few } \\
\text { trials with } \\
\text { limited } \\
\text { randomization } \\
\text { and allocation } \\
\text { information) }\end{array}$ & $\begin{array}{l}\text { Overall, } \\
\text { acetaminophen was } \\
\text { more effective than } \\
\text { placebo in reducing } \\
\text { fever and providing } \\
\text { mild analgesia; it was } \\
\text { less effective than } \\
\text { ibuprofen in fever } \\
\text { control (in children) }\end{array}$ & $\begin{array}{l}\text { Adverse events } \\
\text { higher with } \\
1000 \mathrm{mg} \\
\text { acetaminophen } \\
\text { v. }(25 \% \mathrm{v} .5 \% \text {, } \\
\text { p }<0.001) \text {; } \\
\text { all events were } \\
\text { mild or } \\
\text { moderate (e.g., } \\
\text { sweating) }\end{array}$ & $\begin{array}{l}\text { Likely } \\
\text { effective for } \\
\text { fever and } \\
\text { analgesia v. } \\
\text { placebo; } \\
\text { inferior to } \\
\text { ibuprofen for } \\
\text { fever control }\end{array}$ \\
\hline Antibiotic $^{65}$ & Various antibiotics & $\begin{array}{l}\text { Meta-analysis } \\
\text { (6 RCTs; } n=1047 \\
\text { adults and children) }\end{array}$ & $\begin{array}{l}\text { Moderate (some } \\
\text { trial quality } \\
\text { concerns and } \\
\text { inconsistent results) }\end{array}$ & $\begin{array}{l}\text { No effect on reduction } \\
\text { of persistent symptoms } \\
\text { (risk ratio } 0.95,95 \% \mathrm{Cl} \\
0.59 \text { to } 1.51 \text { ) }\end{array}$ & $\begin{array}{l}\text { Adverse events } \\
\text { increased (relative } \\
\text { risk } 1.8,95 \% \mathrm{Cl} \\
1.01 \text { to } 3.21 \text { ) }\end{array}$ & $\begin{array}{l}\text { No benefit, } \\
\text { and harms } \\
\text { present }\end{array}$ \\
\hline
\end{tabular}


placebo. Two RCTs found a statistically significant improvement in the global assessment of symptoms, with 10\%-15\% more patients in the ipratropium group reporting themselves as "good or better" or "much better or better" on day 1 or 2 (e.g., in one study, $74 \%$ of patients using ipratropium and $61 \%$ of those using placebo rated themselves "much better or better" $[p=0.02])$. Pooled data on adverse events (from up to six RCTs) showed significantly increased epistaxis (OR 3.21, 95\% CI 1.68 to 6.13), nasal dryness (OR $2.55,95 \%$ CI 1.50 to 4.33 ) and dry mouth (OR $3.59,95 \%$ CI 1.38 to 9.38 ).

\section{Over-the-counter cough suppressants}

Over-the-counter cough suppressants are of no benefit for children, and Health Canada recommends against their use in children under the age of six years ${ }^{67}$ For adults, the benefit is unclear but likely small. A systematic review ${ }^{59}$ evaluated a variety of outcomes such as cough and global improvement scores in children (age two to seven years), but statistically significant improvements were infrequent and inconsistent and of doubtful clinical significance. ${ }^{59,68}$ In addition, a Canadian review of codeine for acute cough in children found no benefit when compared with placebo. ${ }^{69}$ In adults, antihistamines and codeine had no effect on cough..$^{59}$ One study of guaifenesin found no benefit; in another, $75 \%$ of participants reported that guaifenesin was helpful for their cough, compared with $31 \%$ given placebo $(p<0.01) .{ }^{59}$ Dextromethorphan had mixed results, with two positive trials showing a $12 \%-36 \%$ improvement in cough scores $(p<0.05) .{ }^{59}$ Combination products seemed to have some benefit, but there is little consistency in outcomes and it is not clear whether all negative outcomes were reported. Poor trial quality, varying reported outcomes and inconsistent results limit interpretation..$^{59}$

\section{Vapour rub}

Vapour rub containing camphor, menthol and eucalyptus oil is applied to the neck and chest. In the one $\mathrm{RCT}^{60}$ we found that assessed its efficacy, harms appeared to outweigh benefits. No effect was found on rhinorrhea. Scores for cough frequency and severity were improved compared with no treatment ( $p=0.006$ or better) but not compared with petrolatum (placebo). Scores for child and parental sleep were both significantly improved with vapour rub versus petrolatum ( $p=$ 0.008 or better). For the combination of all scales (range 6-42), vapour rub had an improved score of about 4 higher than petrolatum $(p=0.03)$. However, significantly increased adverse events over placebo included burning sensation to the skin $(28 \%)$, nose $(14 \%)$ and eyes $(16 \%)(p<$ 0.001 each). Rash and redness of skin each occurred in 5\% of patients using vapour rub, compared with none using petrolatum.

\section{Other interventions}

Nonsteroidal anti-inflammatory drugs and acetaminophen appear to be effective in relieving pain and fever in people with upper respiratory tract infection but not in relieving other symptoms. ${ }^{61-63}$ Ibuprofen has been shown to be superior to acetaminophen in fever control, whereas the safety of these drugs, at least in pediatric populations, is equivalent. ${ }^{64,65}$ Antibiotics have no beneficial effect on the common cold but do increase adverse events. ${ }^{66}$ Because many symptoms of bacterial upper respiratory tract infections overlap with cold symptoms, clinicians may be tempted to prescribe antibiotics. Although prescribing should be minimized, issuing a delayed prescription for an antibiotic at times of uncertainty has been shown to reduce antibiotic use from $93 \%$ to $32 \% .^{70}$

Summarized details of these interventions can be found in Table 2. See also Appendix 1 for a more detailed discussion of each intervention.

\section{What alternative and nonpharmacologic treatments of the common cold are effective?}

Alternative and nonpharmacologic treatments of the common cold are summarized in Table $3 .^{47,50,71-80}$

\section{Honey}

Consistent findings of three RCTs involving children suggest that a single night-time dose of honey can have a small effect on cough and sleep in children over 12 months old. ${ }^{71-73}$ Multiple methodologic issues were present in one or more of the trials, including inadequate description of randomization and allocation, no blinding, exclusion of patients who deviated from the protocol, substitution of clinician ratings in place of parent or child ratings, funding by the Honey Board and uncertain clinical significance..$^{68,71-73}$ There was no consistency in adverse events between the trials. Honey should not be given to children younger than 12 months.

\section{Zinc, oral or intranasal}

Inconsistent evidence from a meta-analysis suggests that orally administered zinc reduces the duration and severity of the common cold in adults. ${ }^{74} \mathrm{~A}$ 23-mg zinc gluconate lozenge every two hours was the most commonly studied regimen, although there was considerable variability across studies in dose ( 4.5 to $23.7 \mathrm{mg}$ ), frequency (twice daily to 10 times daily) and formulations (gluconate, sulfate or acetate)..$^{74}$ Zinc shortened the course of colds significantly (mean difference $-1.65 \mathrm{~d}, 95 \% \mathrm{CI}-2.5$ to 
-0.8 , compared with placebo),${ }^{74}$ a finding similar to but somewhat better than the Cochrane review ${ }^{31}$ (standardized mean difference $-0.97 \mathrm{~d}, 95 \% \mathrm{CI}$ -1.56 to -0.38$)$. However, zinc was found to have no significant effect on the duration of colds in children (mean difference $-0.26,95 \% \mathrm{CI}-0.78$ to 0.25 ), but the effect was significant in adults (mean difference $-2.63,95 \%$ CI -3.69 to -1.58$).{ }^{74}$ Higher doses appeared to be more effective than lower doses. Zinc did not significantly affect symptom severity in children (standard mean difference $-0.05,95 \% \mathrm{CI}-0.27$ to 0.17 ) but did reduce severity in adults (standard mean difference $-0.64,95 \%$ CI -1.05 to -0.24$).{ }^{74}$ Although the data were posi- tive for adults, heterogeneity was consistently high in all results $(I=55 \%$ to $95 \%)$, which reflected a high level of inconsistency, even in subgroup testing. ${ }^{74}$ Use of oral zinc supplements was associated with an increased risk of adverse events such as bad taste and nausea (risk ratio $1.24,95 \%$ CI 1.05 to 1.46). ${ }^{74}$ It is unclear why oral zinc treatment seems to benefit adults more than children.

The evidence to support intranasal use of zinc is weak, and important risks exist. ${ }^{79}$ We found only three RCTs of zinc used intranasally, 0.044 $\mathrm{mg}$ to $2.1 \mathrm{mg}$ daily in four doses. ${ }^{79}$ There was no significant difference in any persisting symptoms at day 3 for all pooled studies, and again the het-

Table 3: Alternative and nonpharmacologic interventions for the treatment of the common cold

\begin{tabular}{|c|c|c|c|c|c|c|}
\hline Intervention & $\begin{array}{l}\text { Formulation } \\
\text { and dose }\end{array}$ & Evidence & Risk of bias & Outcome & Harms & Comment \\
\hline Honey $^{71-73}$ & $\begin{array}{l}2.5-10 \mathrm{mg} \text {, one dose } \\
\text { at bedtime }\end{array}$ & $\begin{array}{l}3 \text { RCTs ( } n=105, \\
139 \text { and } 300 \\
\text { children, } \\
\text { respectively); } \\
\text { most aged } 1-5 \mathrm{yr}\end{array}$ & $\begin{array}{l}\text { Moderate (multiple } \\
\text { trial quality issues, } \\
\text { but results highly } \\
\text { consistent) }\end{array}$ & $\begin{array}{l}\text { Evidence of benefit } \\
\text { over placebo and } \\
\text { dextromethorphan }\end{array}$ & $\begin{array}{l}\text { No consistent } \\
\text { adverse events }\end{array}$ & $\begin{array}{l}\text { Small benefit } \\
\text { for cough in } \\
\text { children } \\
\text { (age > } 1 \mathrm{yr} \text { ); } \\
\text { no data for } \\
\text { adults }\end{array}$ \\
\hline Zinc, oral ${ }^{74}$ & $\begin{array}{l}\text { Different } \\
\text { formulations, doses, } \\
\text { frequency; zinc } \\
\text { gluconate } 23-\mathrm{mg} \\
\text { lozenge every } 2 \mathrm{~h} \\
\text { most common }\end{array}$ & $\begin{array}{l}\text { Meta-analysis } \\
(17 \text { RCTs, } \\
n=2121)\end{array}$ & $\begin{array}{l}\text { Moderate (high or } \\
\text { moderate risk of } \\
\text { bias in many studies) }\end{array}$ & $\begin{array}{l}\text { Pooled analysis of } 8 \\
\text { RCTs: reduced duration } \\
\text { of cold (mean } \\
\text { difference }-1.65 \mathrm{~d} \text {, } \\
95 \% \mathrm{Cl}-2.5 \text { to }-0.8 \text { ) }\end{array}$ & $\begin{array}{l}\text { Increased } \\
\text { adverse events } \\
\text { (bad taste and } \\
\text { nausea) }\end{array}$ & $\begin{array}{l}\text { Probable } \\
\text { benefit in } \\
\text { adults, but } \\
\text { harms present; } \\
\text { no benefit in } \\
\text { children }\end{array}$ \\
\hline $\begin{array}{l}\text { Nasal } \\
\text { irrigation }^{75}\end{array}$ & $\begin{array}{l}\text { Generally, saline } \\
\text { drops (children) or } \\
\text { irrigation }\end{array}$ & $\begin{array}{l}\text { Systematic } \\
\text { review and meta- } \\
\text { analysis (3 RCTs, } \\
n=618 \text { ) }\end{array}$ & $\begin{array}{l}\text { High (multiple } \\
\text { outcomes, most } \\
\text { nonsignificant, and } \\
\text { quality issues in RCTs) }\end{array}$ & $\begin{array}{l}\text { Pooled analysis of } 2 \\
\text { RCTs: no difference in } \\
\text { nasal symptom score; } \\
\text { other results } \\
\text { inconsistent }\end{array}$ & $\begin{array}{l}13 \% \text { nasal } \\
\text { irritation, } 30 \% \\
\text { dry nose, } 40 \% \text { of } \\
\text { infants intolerant } \\
\text { of nasal drops }\end{array}$ & $\begin{array}{l}\text { Unclear } \\
\text { benefit }\end{array}$ \\
\hline Humidified air ${ }^{76}$ & $\begin{array}{l}\text { Heated water } \\
\left(42^{\circ} \mathrm{C}-47^{\circ} \mathrm{C}\right) \text {, } \\
\text { vapourized }\end{array}$ & $\begin{array}{l}\text { Systematic } \\
\text { review and meta- } \\
\text { analysis (6 RCTs, } \\
n=394)\end{array}$ & $\begin{array}{l}\text { Moderate (unclear } \\
\text { allocation } \\
\text { concealment and } \\
\text { mixed results) }\end{array}$ & $\begin{array}{l}\text { Pooled analysis of } 2 \text { RCTs: } \\
\text { fewer participants with } \\
\text { persistent symptoms (Peto } \\
\text { OR } 0.31,95 \% \mathrm{Cl} 0.16 \text { to } \\
0.60) \text {; very inconsistent } \\
\text { results }\left(I^{2}=89 \%\right)\end{array}$ & $\begin{array}{l}\text { Increased } \\
\text { harms, } \\
\text { including mask } \\
\text { discomfort and } \\
\text { increased nasal } \\
\text { congestion }\end{array}$ & $\begin{array}{l}\text { Unclear } \\
\text { benefit }\end{array}$ \\
\hline Echinacea $^{50}$ & $\begin{array}{l}\text { Variable formulations } \\
\text { and dosing; } \\
\text { E. purpurea most } \\
\text { common }\end{array}$ & $\begin{array}{l}\text { Systematic } \\
\text { review (14 RCTs, } \\
n=2090)\end{array}$ & $\begin{array}{l}\text { Moderate (some trial } \\
\text { quality issues, and } \\
\text { inconsistent } \\
\text { formulations, cold } \\
\text { definitions and results) }\end{array}$ & $\begin{array}{l}\text { Inconsistent results (not } \\
\text { pooled); for example, } \\
1 \text { of } 6 \text { studies showed } \\
\text { improved duration and } \\
\text { severity of symptoms }\end{array}$ & $\begin{array}{l}\text { No evidence of } \\
\text { harms }\end{array}$ & $\begin{array}{l}\text { Unclear } \\
\text { benefit }\end{array}$ \\
\hline $\begin{array}{l}\text { Chinese } \\
\text { medicinal herbs }{ }^{77}\end{array}$ & Various formulations & $\begin{array}{l}\text { Systematic } \\
\text { review (17 RCTs, } \\
n=3212)\end{array}$ & $\begin{array}{l}\text { High (poor trial } \\
\text { quality) }\end{array}$ & $\begin{array}{l}\text { Data not pooled; } 1 \text { of } 17 \\
\text { RCTs showed improved } \\
\text { severity of symptoms }\end{array}$ & Not reported & $\begin{array}{l}\text { Unclear (likely } \\
\text { no) benefit }\end{array}$ \\
\hline Ginseng $^{78}$ & $\begin{array}{l}\text { North American ginseng } \\
\text { extract in standard dose } \\
\text { ( } 26 \mathrm{mg} / \mathrm{kg} \text { on day } 1 \text {, } \\
17 \mathrm{mg} / \mathrm{kg} \text { on day } 2 \text {, } \\
9 \mathrm{mg} / \mathrm{kg} \text { on day } 3 \text { ) v. low } \\
\text { dose (half the amounts } \\
\text { on each day) v. placebo }\end{array}$ & $\begin{array}{l}1 \mathrm{RCT}(n=46 \\
\text { children aged } \\
3-12 \mathrm{yr} \text { ) }\end{array}$ & $\begin{array}{l}\text { Low (high-quality } \\
\text { trial) }\end{array}$ & No effects reported & $\begin{array}{l}\text { No increase in } \\
\text { adverse events }\end{array}$ & $\begin{array}{l}\text { Unclear } \\
\text { benefit }\end{array}$ \\
\hline Vitamin $C^{47}$ & $1.5-4 \mathrm{~g}$ for $1-5 \mathrm{~d}$ & $\begin{array}{l}\text { Meta-analysis } \\
\text { ( } 7 \text { trials, } n=3294 \\
\text { colds) }\end{array}$ & $\begin{array}{l}\text { Moderate (reviewers } \\
\text { used blinding as a } \\
\text { surrogate of allocation } \\
\text { concealment) }\end{array}$ & $\begin{array}{l}\text { Pooled analysis of } 7 \\
\text { RCTs: no effect on } \\
\text { duration }\end{array}$ & $\begin{array}{l}\text { No evidence of } \\
\text { harms }\end{array}$ & No benefit \\
\hline $\begin{array}{l}\text { Zinc, } \\
\text { intranasal }\end{array}$ & $\begin{array}{l}\text { Zinc nasal spray } \\
33 \mathrm{mmol} / \mathrm{L} \text {, each } \\
\text { nostril } 4 \text { times daily } \\
\text { ( } 2.1 \mathrm{mg} \text { total) in } 2 \text { of } 3 \\
\text { studies }\end{array}$ & $\begin{array}{l}\text { Meta-analysis } \\
\text { (3 studies, } \\
n=453 \text { ) }\end{array}$ & $\begin{array}{l}\text { Moderate (high } \\
\text { heterogeneity, } \\
\text { possible nonblinding } \\
\text { and poor description } \\
\text { of randomization) }\end{array}$ & $\begin{array}{l}\text { Pooled analysis of } 3 \\
\text { RCTs: no significant } \\
\text { effect on presence of } \\
\text { symptoms at day } 3\end{array}$ & $\begin{array}{l}\text { Nasal burning } \\
\text { and stinging; } \\
\text { unresolved } \\
\text { concern of } \\
\text { permanent loss } \\
\text { of smell }\end{array}$ & $\begin{array}{l}\text { Do not use } \\
\text { (unclear } \\
\text { benefit and } \\
\text { possible } \\
\text { serious harm } \\
\text { may exist) }\end{array}$ \\
\hline
\end{tabular}


erogeneity was very high $\left(I^{2}=99 \%\right)$. Adverse events such as nasal stinging and burning were more common with zinc used intranasally than with placebo. In addition, anosmia was described in a case series, ${ }^{80}$ and a US manufacturer settled legal claims for anosmia. ${ }^{79}$

\section{Other interventions}

Although seven trials with more than 3000 patients examined vitamin $\mathrm{C}$ for the treatment of the common cold, no clear benefit was shown. ${ }^{47}$ It is not possible to determine whether benefit exists for most other alternative therapies. Studies of nasal irrigation, ${ }^{75}$ humidified air, ${ }^{76}$ Chinese herbal medicines ${ }^{77}$ and echinacea ${ }^{50}$ all showed inconsistent results. A single clinical trial of ginseng did not report efficacy outcomes. ${ }^{78}$ We did not identify any high-level evidence for garlic or probiotics in the treatment of the common cold.

Summarized details of these interventions can be found in Table 3. See also Appendix 1 for a more detailed discussion of each intervention.

\section{Unanswered questions}

In 1931, the author of a CMAJ article on the common cold said, "The common cold is so common that we are apt to pass it by with a contemptuous gesture, unless, of course, we are the sufferers ourselves." ${ }^{81}$

Much more evidence now exists in this area, but many uncertainties remain regarding interventions to prevent and treat the common cold. We focused on RCTs and systematic reviews and meta-analyses of RCTs for therapy, but few of the studies had a low risk of bias. However, many of the results were inconsistent and had small effects (e.g., vitamin C), which arouses suspicion that any noted benefit may represent bias rather than a true effect. ${ }^{82}$ We encourage researchers to perform well-designed RCTs on promising treatments or on preventive methods with limited evidence (i.e., gargling or garlic). Further work to help clinicians clearly distinguish the common cold from other upper respiratory tract infections would also be useful.

\section{References}

1. Heikkinen T, Järvinen A. The common cold. Lancet 2003;361:51-9.

2. Lessler J, Reich NG, Brookmeyer R, et al. Incubation periods of acute respiratory viral infections: a systematic review. Lancet Infect Dis 2009;9:291-300.

3. Lober B. The common cold. J Gen Intern Med 1996;11:229-36.

4. Arruda E, Pitkäranta A, Witek TJ Jr, et al. Frequency and natural history of rhinovirus infections in adults during autumn. J Clin Microbiol 1997;35:2864-8.

5. Leder K, Sinclair MI, Mitakakis TZ, et al. A community-based study of respiratory episodes in Melbourne, Australia. Aust N Z J Public Health 2003;27:399-404.

6. Monto AS, Sullivan KM. Acute respiratory illness in the community. Frequency of illness and the agents involved. Epidemiol Infect 1993;110:145-60.
7. Monto AS. Epidemiology of viral respiratory infections. Am J Med 2002;112(Suppl 6A):4S-12S.

8. Nicholson KG, Kent J, Hammersley V, et al. Acute viral infections of upper respiratory tract in elderly people living in the community: comparative, prospective, population based study of disease burden. BMJ 1997;315:1060-4.

9. Kvaerner KJ, Nafstad P, Jaakkola JJ. Upper respiratory morbidity in preschool children: a cross-sectional study. Arch Otolaryngol Head Neck Surg 2000;126:1201-6.

10. Cohen S, Tyrrell DA, Smith AP. Psychological stress and susceptibility to the common cold. N Engl J Med 1991;325:606-12.

11. Cohen S, Doyle WJ, Alper CM, et al. Sleep habits and susceptibility to the common cold. Arch Intern Med 2009;169:62-7.

12. Ball TM, Holberg CJ, Aldous MB, et al. Influence of attendance at day care on the common cold from birth through 13 years of age. Arch Pediatr Adolesc Med 2002;156:121-6.

13. Mäkelä MJ, Puhakka T, Ruuskanen O, et al. Viruses and bacteria in the etiology of the common cold. J Clin Microbiol 1998:36:539-42.

14. Smith A, Thomas M, Whitney H. Effects of upper respiratory tract illnesses on mood and performance over the working day. Ergonomics 2000;43:752-63.

15. Bramley TJ, Lerner D, Sames M. Productivity losses related to the common cold. J Occup Environ Med 2002;44:822-9.

16. Smith AP, Jamson S. An investigation of the effects of the common cold on simulated driving performance and detection of collisions: a laboratory study. BMJ Open 2012;2:pii:e001047.

17. Fendrick AM, Monto AS, Nightengale B, et al. The economic burden of non-influenza-related viral respiratory tract infection in the United States. Arch Intern Med 2003;163:487-94.

18. Vingilis ER, Brown U, Sarkella J, et al. Cold/flu knowledge, attitudes and health care practices: results of a two-city telephone survey. Can J Public Health 1999;90:205-8.

19. Sauro A, Barone F, Blasio G, et al. Do influenza and acute respiratory infective diseases weigh heavily on general practitioners' daily practice? Eur J Gen Pract 2006;12:34-6.

20. McIsaac WJ, White D, Tannenbaum D, et al. A clinical score to reduce unnecessary antibiotic use in patients with sore throat CMAJ 1998; 158:75-83.

21. Chow AW, Benninger MS, Brook I, et al.; Infectious Diseases Society of America. IDSA clinical practice guideline for acute bacterial rhinosinusitis in children and adults. Clin Infect Dis 2012; 54:e72-112

22. Smith SR, Montgomery LG, Williams JW Jr. Treatment of mild to moderate sinusitis. Arch Intern Med 2012;172:510-3.

23. Rothman R, Owens T, Simel DL. Does this child have acute otitis media? JAMA 2003;290:1633-40.

24. Forgie S, Zhanel G, Robinson J; Canadian Paediatric Society, Infectious Diseases and Immunization Committee. Management of acute otitis media [position statement]. Ottawa (ON): Canadian Paediatric Society; 2009. Available: www.cps.ca/en /documents/position/acute-otitis-media (accessed 2012 Aug. 2).

25. Angier E, Willington J, Scadding G, et al. British Society for Allergy and Clinical Immunology (BSACI) Standards of Care Committee. Management of allergic and non-allergic rhinitis: a primary care summary of the BSACI guideline. Prim Care Respir J 2010;19:217-22.

26. Pelucchi C, Grigoryan L, Galeone C, et al.; ESCMID Sore Throat Guideline Group. Guideline for the management of acute sore throat. Clin Microbiol Infect 2012;18(Suppl 1):1-28.

27. Antiviral agents for the treatment and chemoprophylaxis of influenza - recommendations of the Advisory Committee on Immunization Practices (ACIP). MMWR Recomm Rep 2011;60:1-24.

28. Prevention and control of influenza with vaccines: recommendations of the Advisory Committee on Immunization Practices (ACIP), 2011. MMWR Morb Mortal Wkly Rep 2011;60:1128-32.

29. Little P, Coote N, Joshua A, et al. Respiratory tract infections antibiotic prescribing: prescribing of antibiotics for self-limiting respiratory tract infections in adults and children in primary care [guideline no. CG69]. London (UK): National Institute for Health and Care Excellence; 2008. Available: http://publications.nice.org .uk/respiratory-tract-infections-antibiotic-prescribing-cg69 (accessed 2012 Aug. 2)

30. Jefferson T, Del Mar CB, Dooley L, et al. Physical interventions to interrupt or reduce the spread of respiratory viruses. Cochrane Database Syst Rev 2011;(7):CD006207.

31. Singh M, Das RR. Zinc for the common cold. Cochrane Database Syst Rev 2011;(2):CD001364.

32. Kurugöl Z, Akilli M, Bayram N, et al. The prophylactic and therapeutic effectiveness of zinc sulphate on common cold in children. Acta Paediatr 2006;95:1175-81.

33. Vakili R, Vahedian M, Khodaei GH, et al. Effects of zinc supplementation in occurrence and duration of common cold in school aged children during cold season: a double-blind placebocontrolled trial. Iran J Pediatr 2009; 19:376-80. 
34. Hao Q, Lu Z, Dong BR, et al. Probiotics for preventing acute upper respiratory tract infections. Cochrane Database Syst Rev 2011; (9):CD006895.

35. Merenstein D, Murphy M, Fokar A, et al. Use of a fermented dairy probiotic drink containing Lactobacillus casei (DN-114 001) to decrease the rate of illness in kids: the DRINK study. A patientoriented, double-blind, cluster-randomized, placebo-controlled, clinical trial. Eur J Clin Nutr 2010;64:669-77.

36. Hojsak I, Abdovic S, Szajewska H, et al. Lactobacillus GG in the prevention of nosocomial gastrointestinal and respiratory tract infections. Pediatrics 2010;125:e1171-7.

37. Satomura K, Kitamura T, Kawamura T, et al. Prevention of upper respiratory tract infections by gargling: a randomized trial. Am J Prev Med 2005;29:302-7.

38. Seida JK, Durec T, Kuhle S. North American (Panax quinquefolius) and Asian Ginseng (Panax ginseng) preparations for prevention of the common cold in healthy adults: a systematic review. Evid Based Complement Alternat Med 2011;2011:282151.

39. McElhaney JE, Simor AE, McNeil S, et al. Efficacy and safety of CVT-E002, a proprietary extract of Panax quinquefolius in the prevention of respiratory infections in influenza-vaccinated community-dwelling adults: a multicenter, randomized, double-blind, and placebo-controlled trial. Influenza Res Treat 2011; article ID 759051.

40. Kolber MR, McCormack J. COLD FX ${ }^{\circledR}$ evidence: consistently reported inconsistently. In: Tools for Practice [newsletter] Edmonton (AB): Alberta College of Family Physicians; 2011. Available: www.acfp.ca/Portals/0/docs/TFP/20111213 065849 .pdf (accessed 2012 Aug. 2)

41. Chubak J, McTiernan A, Sorensen B, et al. Moderate-intensity exercise reduces the incidence of colds among postmenopausal women. Am J Med 2006;119:937-42.

42. Lissiman E, Bhasale AL, Cohen M. Garlic for the common cold Cochrane Database Syst Rev 2012;(3):CD006206.

43. Josling P. Preventing the common cold with a garlic supplement: a double-blind, placebo-controlled survey. Adv Ther 2001;18:189-93.

44. de Lange de Klerk ES, Blommers J, Kuik DJ, et al. Effect of homoeopathic medicines on daily burden of symptoms in children with recurrent upper respiratory tract infections. BMJ 1994; 309:1329-32.

45. Steinsbekk A, Bentzen N, Fønnebø V, et al. Self-treatment with one of three self-selected, ultramolecular homeopathic medicines for the prevention of upper respiratory tract infections in children. A double-blind randomized placebo controlled trial. $\mathrm{Br}$ J Clin Pharmacol 2005;59:447-55.

46. Steinsbekk A, Fønnebø V, Lewith G, et al. Homeopathic care for the prevention of upper respiratory tract infections in children: a pragmatic, randomised, controlled trial comparing individualised homeopathic care and waiting-list controls. Complement Ther Med 2005;13:231-8.

47. Dougals RM, Hemilä H, Chalker E. Vitamin C for preventing and treating the common cold. Cochrane Database Syst Rev 2007;(3): CD000980.

48. Laaksi I, Ruohola JP, Mattila V, et al. Vitamin D supplementation for the prevention of acute respiratory tract infection: a randomized, double-blinded trial among young Finnish men. J Infect Dis 2010;202:809-14.

49. Murdoch DR, Slow S, Chambers ST, et al. Effect of vitamin D3 supplementation on upper respiratory tract infections in healthy adults: the VIDARIS randomized controlled trial. JAMA 2012; 308:1333-9.

50. Linde K, Barrett B, Wölkart K, et al. Echinacea for preventing and treating the common cold. Cochrane Database Syst Rev 2006;(1):CD000530.

51. D'Agostino RB Sr, Weintraub M, Russell HK, et al. The effectiveness of antihistamines in reducing the severity of runny nose and sneezing: a meta-analysis. Clin Pharmacol Ther 1998;64:579-96.

52. Sutter AI, Lemiengre M, Campbell H, et al. Antihistamines for the common cold. Cochrane Database Syst Rev 2003;(3):CD001267.

53. De Sutter AIM, van Driel ML, Kumar AA, et al. Oral antihistamine-decongestant-analgesic combinations for the common cold. Cochrane Database Syst Rev 2012;2:CD004976.

54. Kollar C, Schneider H, Waksman J, et al. Meta-analysis of the efficacy of a single dose of phenylephrine $10 \mathrm{mg}$ compared with placebo in adults with acute nasal congestion due to the common cold. Clin Ther 2007;29:1057-70.

55. Hatton RC, Winterstein AG, McKelvey RP, et al. Efficacy and safety of oral phenylephrine: systematic review and metaanalysis. Ann Pharmacother 2007;41:381-90.

56. Taverner D, Latte J. Nasal decongestants for the common cold [abstract]. Cochrane Database Syst Rev 2007;(1):CD001953.

57. Eccles R, Martensson K, Chen SC. Effects of intranasa xylometazoline, alone or in combination with ipratropium, in patients with common cold. Curr Med Res Opin 2010;26:889-99.

58. Albalawi ZH, Othman SS, Alfaleh K. Intranasal ipratropium bromide for the common cold. Cochrane Database Syst Rev 2011;(7):CD008231.

59. Smith SM, Schroeder K, Fahey T. Over-the-counter (OTC) medications for acute cough in children and adults in ambulatory settings. Cochrane Database Syst Rev 2008;(1):CD001831.

60. Paul IM, Beiler JS, King TS, et al. Vapor rub, petrolatum, and no treatment for children with nocturnal cough and cold symptoms. Pediatrics 2010;126:1092-9.

61. Kim SY, Cho HM, Hwang YW, et al. Non-steroidal anti-inflammatory drugs for the common cold. Cochrane Database Syst Rev 2009;(3):CD006362.

62. Bachert C, Chuchalin AG, Eisebitt R, et al. Aspirin compared with acetaminophen in the treatment of fever and other symptoms of upper respiratory tract infection in adults: a multicenter, randomized, double-blind, double-dummy, placebo-controlled, parallel-group, single-dose, 6-hour dose-ranging study. Clin Ther 2005;27:993-1003.

63. Ulukol B, Köksal Y, Cin S. Assessment of the efficacy and safety of paracetamol, ibuprofen and nimesulide in children with upper respiratory tract infections. Eur J Clin Pharmacol 1999;55:615-8.

64. Perrott DA, Piira T, Goodenough B, et al. Efficacy and safety of acetaminophen vs. ibuprofen for treating children's pain or fever: a meta-analysis. Arch Pediatr Adolesc Med 2004;158:521-6.

65. Pierce CA, Voss B. Efficacy and safety of ibuprofen and acetaminophen in children and adults: a meta-analysis and qualitative review. Ann Pharmacother 2010;44:489-506.

66. Arroll B, Kenealy T. Antibiotics for the common cold and acute purulent rhinitis. Cochrane Database Syst Rev 2005;(3):CD000247.

67. Health Canada releases decision on the labelling of cough and cold products for children. Ottawa (ON): Health Canada; 2008. Available: www.healthycanadians.gc.ca/recall-alert-rappel-avis /hc-sc/2008/13267a-eng.php (accessed 2013 Oct. 24).

68. Allan GM, Korownyk C, Kolber M. Do cough suppressants or honey help pediatric cough? Can Fam Physician 2011;57:435.

69. Goldman RD. Codeine for acute cough in children. Can Fam Physician 2010;56:1293-4.

70. Ivers N, Arroll B, Allan GM. Delayed antibiotic prescriptions for URTIs. Can Fam Physician 2011;57:1287.

71. Paul IM, Beiler J, McMonagle A, et al. Effect of honey, dextromethorphan, and no treatment on nocturnal cough and sleep quality for coughing children and their parents. Arch Pediatr Adolesc Med 2007;161:1140-6.

72. Shadkam MN, Mozaffari-Khosravi H, Mozayan MR. A comparison of the effect of honey, dextromethorphan, and diphenhydramine on nightly cough and sleep quality in children and their parents. J Altern Complement Med 2010;16:787-93.

73. Cohen HA, Rozen J, Kristal H, et al. Effect of honey on nocturnal cough and sleep quality: double-blind a. randomized, placebo-controlled study. Pediatrics 2012;130:465-71.

74. Science M, Johnstone J, Roth DE, et al. Zinc for the treatment of the common cold: a systematic review and meta-analysis of randomized controlled trials. CMAJ 2012;184:E551-61.

75. Kassel JC, King D, Spurling GKP. Saline nasal irrigation for acute upper respiratory tract infections. Cochrane Database Syst Rev 2010;(3):CD006821

76. Singh M, Singh M. Heated, humidified air for the common cold. Cochrane Database Syst Rev 2011;(5):CD001728.

77. Wu T, Zhang J, Qiu Yet al. Chinese medicinal herbs for the common cold. Cochrane Database Syst Rev 2007;(1):CD004782.

78. Vohra S, Johnston BC, Laycock KL, et al. Safety and tolerability of North American ginseng extract in the treatment of pediatric upper respiratory tract infection: a phase II randomized, controlled trial of 2 dosing schedules. Pediatrics 2008;122:e402-10

79. D'Cruze H, Arroll B, Kenealy T. Is intranasal zinc effective and safe for the common cold? A systematic review and meta-analysis. J Prim Health Care 2009;1:134-9.

80. Jafek BW, Linschoten MR, Murrow BW. Anosmia after intranasal zinc gluconate use. Am J Rhinol 2004;18:137-41.

81. AGN. Recent studies on "the common cold." CMAJ 1931;25:455-6.

82. Ioannidis JP. Why most published research findings are false. PLoS Med 2005;2:e124.

Affiliations: Evidence-Based Medicine, Department of Family Medicine (Allan), University of Alberta, Edmonton, Alta.; Department of General Practice and Primary Health Care (Arroll), University of Auckland, Auckland, New Zealand.

Contributors: Michael Allan and Bruce Arroll independently searched and reviewed the evidence. Michael Allan prepared the first evidence summary and draft of the article. Bruce Arroll confirmed the evidence summary and edited the draft critically for content. Both authors approved the final version submitted for publication. 